\title{
Live to Tell: Remediating Historical Performance in the Popular Music Biopic
}

\author{
Maurizio Corbella \\ University of Milan, Italy \\ corbellamaurizio@gmail.com
}

\begin{abstract}
This article explores some of the procedures through which popular music biopics remediate, reactivate, authenticate and in some cases newly create the aura of key performances in the history of popular music. Biopics are not intended as mere story-tellers but as sensory remediators of musical performance. Historical musical events are "reperformed" for a new composite audience, part of which is familiar with the music, and part experiencing it for the first time. For the performative potential of a past musical event to be reactivated, its affordance is updated using current production values. In order to accomplish this, biopics deploy an array of constructive devices. Though the focus is on the contemporary renaissance of the biopic genre, with two recent cases analysed in detail - Walk the Line (2005), about the life of Johnny Cash, and Get On Up (2014), on the rise of James Brown - the starting point for this survey is a less recent example, The Buddy Holly Story (1978).

KEYWORDS: popular music biopic, popular music performance, remediation, authenticity and authentication, mediatization, performance in film
\end{abstract}




\section{Introduction: the popular music biopic and canonised performance}

While most biographical films (biopics) about popular musicians feature performance scenes, not all of them deal overtly or primarily with concerts that have been subjected to a process of historical canonization. However, it would appear that this trend has become increasingly prevalent in recent and contemporary examples, a phenomenon perhaps linked to the "neoclassical" qualities that Dennis Bingham (2010:17-18) has detected in contemporary biopics. By definition, neoclassicism measures itself against a canon of "classics", and the contemporary popular music biopic deals more explicitly today than it did in the past with the progressive crystallization of the rock canon (Jones, 2008), attracting higher production values and budgets. One distinctive aspect of the relation of contemporary biopics to history, which also affects musical representations, is their different take on archival media materials. As Belén Vidal (2014: 21-22) has pointed out:

The international biopic has taken a notable turn to the visual and sonic archive of the twentieth century. At a time of veritable visual-media saturation, available archival materials (and their digital reconstructions) often crowd the screen, standing side by side or blending with dramatic reenactment. Archival images and sounds form the textures of memory, whether individual or collective. The focus on the unique individual can thus open up to a mode of address that appeals to the spectator's sense of remembrance and participation in a shared popular culture (...), a sense of community through a shared past (...), or [that] can directly challenge the consensual sense of history.

Memorable performances play a major role in the process of the canonization of popular music stars. Unsurprisingly, they tend to gain the foreground in the dramaturgies of recent biopics. A selective list should suffice to exemplify this trend:

- A prototype of contemporary biopics such as The Doors (dir. Stone, 1991) treats the first live performance of the Oedipal section of "The End" (Whisky a Go Go, Los Angeles, August 1966) as a sort of initiation rite for the film audience.

- Walk the Line (dir. Mangold, 2005) frames its entire account of Johnny Cash's biography as a flashback unwinding in the space of an instant preceding Cash's concert at Folsom Prison in 1968.

- Get On Up (dir. T. Taylor, 2014) deals with several historical performances, as for instance James Brown's concert at the Boston Garden (5 April 1968) the day after the assassination of Martin Luther King. 
- Jimi: Al/ Is by My Side (dir. Ridley, 2013) is teleologically constructed so as to point towards Hendrix's appearance at Monterey Pop Festival in 1967, but excludes the performance from the film, relegating it to the end credits.

- One of the few open references to a historical performance in the otherwise atypical I'm Not There (dir. Haynes, 2007) is Bob Dylan's electric switch at the Newport Folk Festival in 1965.

- Finally, La Vie en Rose (La môme, dir. Dahan, 2007) culminates in Edith Piaf's return to the scene at the Olympia in 1960.

The question I would like to raise in this article concerns the kind of relationship that biopics have with historical performances. My suggestion is that biopics remediate, reactivate, authenticate and in some cases newly create the aura of past performances. Following Walter Benjamin's (2002: 447) distinction between "trace" and "aura", ${ }^{1}$ I could rephrase this concept by suggesting that, in fabricating a trace of past performances, biopics seek to convey their aura. I am interested in detailing the procedures through which this occurs, for I find that some of the features that account for the biopic's ability to (re-/de-)construct public history (Custen, 1992) lie in those very aspects that might generally be viewed as "technicalities". My argument is that biopics do not merely act as storytellers, but as sensory remediators. ${ }^{2}$ Historical musical events are somewhat re-performed for a new composite audience, part of which is familiar with the music and part experiencing it for the first time. The aura of a past event is translated into a narrative audiovisual medium that posits a contract based on trust and suspension of disbelief with the audience. From a perceptual point of view, what happens is that for the performative potential of a past musical event to be reactivated, its sensory affordance is updated using modern production values. In order to accomplish this, biopics deploy an array of constructive devices, including, for example: the seamless combination of original/re-edited/re-staged documentary or televised footage; real audiences reacting to actors newly performing/covering/play-backing musical numbers; the enrichment/remix/re-spatialization of original audio tracks through the means of contemporary sound design. These devices appear to conjure up affective experiences of music history that draw on embodiment, witnessing, memory and nostalgia, but at the same time they may surreptitiously promote industrial paradigms of sensory stimulation which are charged with ideological and political implications.

Performance scenes in popular music biopics are usually meta-reflexive devices: they correspond to those moments in a film in which music manifests itself as music and can thus be related to the wider sociocultural spheres of affectivity, morals, race and gender identity, and so forth. At the same time, and more decidedly than in the twin genre of the music documentary, biopics are compelled to reinvent and re-imagine scenes of music making, adding a wealth of new media artifices and interpretations. $^{3}$ When referring to canonized events, disparate kinds of documentation (anecdotal, written, photographic, audio and audiovisual, etc.) may 
pre-date the film, and can be drawn on or neglected in several different guises depending on the extent to which the documentary material has affected the public perception of a musician or a musical style. Biopics may interpolate or restage preexisting audiovisual footage, or they may disregard it for different reasons ranging from concrete problems (such as copyright licensing) to abstract aesthetic considerations (for example the wish to propose a different take on a highly auratic event). What usually persists in a remediated performance is the music, which constitutes the most direct link between the events referred to and the present experience; nevertheless, the musical rendering of a performance scene usually results in a range of creative combinations involving both pre-existing materials (e.g. an official studio/concert recording) and newly devised solutions.

I shall explore these issues by drawing on three case studies, each of which differs both in terms of the nature of the pre-existing material relating to the performance and with regard to the strategies used to accomplish its remediation. In the first example I address a fictional performance loosely based on a legendary yet little-documented historical event and show how its constructive features convey a nostalgic reading of Buddy Holly's musical legacy. In the second I tackle the way in which a canonized live album, i.e. Johnny Cash's At Folsom Prison, is remediated into a narrative device to serve the dramaturgy of a mainstream neoclassical biopic. Lastly, in the third example I engage with the way in which contemporary sound design techniques seamlessly shape the perception of presentday filmgoers with respect to a socio-politically charged event such as James Brown's concert at Boston Garden on 5 April 1968.

\section{The evening before "the day the music died": The Buddy Holly Story (1978)}

In its treatment of performance, The Buddy Holly Story (Rash, 1978) combines elements of the jukebox musical (see James 2016: 33-54) with a narrative structure promoting nostalgia. This nostalgic/canonizing attitude, however, plays out counter-intuitively. Contrary to the emphasis that most other biographical accounts of Buddy Holly's life place on the infamous plane crash of 3 February 1959, which cost him his life, as well as those of Ritchie Valens, J.P. "The Big Bopper" Richardson and pilot Roger Peterson, the film effectively excludes this episode altogether from its storyline and limits itself to recounting it in a final caption (Fig. 1b). ${ }^{4}$ What it does instead is to focus on the performance at Surf Ballroom, Clear Lake, lowa, on the evening before the accident.

The stop-motion shot in Figure 1 corresponds to the end of the performance: while playing the coda of the last song of his set, Buddy Holly (Gary Busey) calls Ritchie Valens (Gilbert Melgar) and The Big Bopper (Gailard Sartain) on stage. As he bids goodbye to his audience with the sadly ironic words "We love you, I'll see 
you next year", Busey/Holly's gesture is frozen (Fig. 1a), while the audio of the cheering audience fades out to leave an uncanny reverberation as a superimposed caption comes into view in an unreal instant of silence. Only after a few moments, when the second sentence "... and the rest is rock ' $n$ ' roll" appears (Fig. 1b), does the music of the end-credits begin. As the credits scroll, an almost imperceptible zoom-in movement slowly reaches a close-up of Busey's face (Fig. 1c) before the film fades to black.

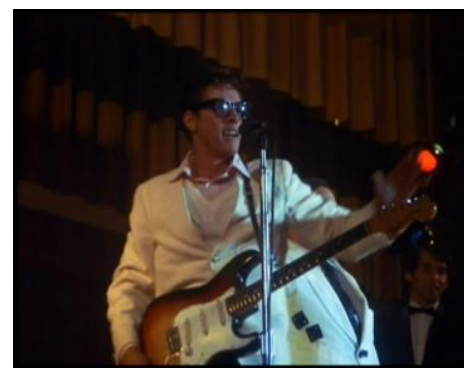

a

b
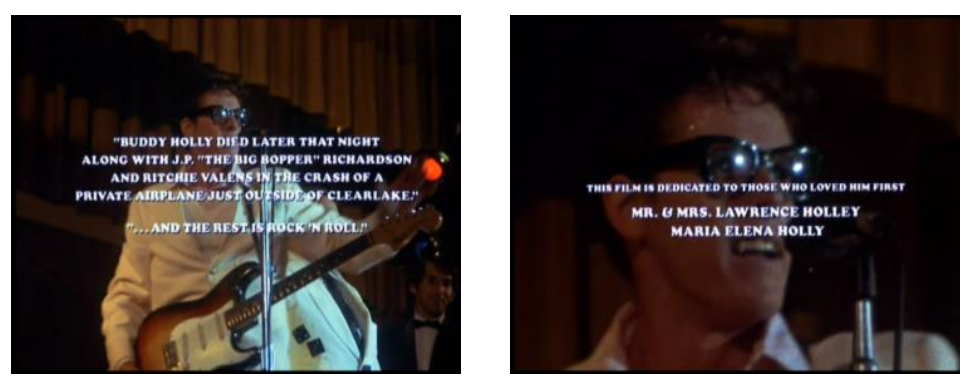

C

FIGURE 1. The Buddy Holly Story (dir. Rash, 1978), film stills (a: 1:50:40; b: 1:50:51; c: 1:54:00). Innovisions - ECA Productions - Columbia Pictures.

The end-credits cue is an instrumental arrangement of "True Love Ways", the song that the film audience has heard a few minutes earlier as the first number of the performance. The choice to open the set with "True Love Ways" is presented in the film as Holly's spontaneous decision, made after talking with his wife on the phone backstage. ${ }^{5}$ Though I was not able to find evidence as to whether Holly actually performed "True Love Ways" on his last gig at Surf Ballroom, it is worth noting that all the six songs presented in the film's final performance (see Table 1) were included in the usual set list of the Winter Dance Party Tour, at least to the extent it has been reconstructed by biographers (Norman 1996: 320; Laing 2010: 74). What emerges clearly from the film, however, is the intentional emphasis on "True Love Ways". Written in 1959 and released posthumously in 1960, the ballad became one of Holly's most successful singles, due also to the epitaph value it acquired after the musician's death: Holly had dedicated it to his wife María Elena, who was pregnant at the time of the tour. Moreover, according to her own recollection, "When Buddy went onstage, he'd get Ritchie [Valens] to hold the phone, so that I could hear him singing 'True Love Ways'. I always knew he was singing that one just for me" (quoted in Norman 1996: 325).

The narrative centrality of the ballad may be a reason why the film takes the artistic freedom of accompanying Holly with a big ensemble including horns, string section, piano and conductor-in line with the arrangement of the song's record release (Coral, 1960)—whereas Holly's Winter Dance Party Tour line-up consisted merely of Tommy Allsup (lead guitar), Waylon Jennings (bass) and Carl Bunch (drums). ${ }^{6}$ The list of artistic licences contained in the performance of "True Love 
Ways" is completed by the fact that King Curtis is announced as playing the saxophone solo, regardless of the fact that he did not take part in the Winter Dance Party Tour nor in the song's recording. ${ }^{7}$ Rather than lament the inaccuracy of the film, however, I would argue that its historical imprecision is motivated by Rash's clear intent to surround the event in a fabled atmosphere. The elements which are imaginatively conflated here are not untrue per se: Holly had indeed started to introduce larger ensembles in his combo arrangements in the last year of his life; moreover, his posthumously-released collaborations with King Curtis on "Come Back Baby" and "Reminiscing" (Choral, 1963) apparently left Holly eager "to build more such bridges between rock ' $n$ ' roll and black soul" (Norman 1996: 291). The film therefore suggests in a very concise and "performative" way the canonical "truth" as to how Holly had started a process of transformation that precociously brought him to become a classic of American music, an icon for the mainstream, rather than a rebellious rock ' $n$ ' roll teen star. Joe Renzetti's arrangements for rock combo and ensemble, which earned him an Academy Award for "Best Adaptation Score", pay tribute to this idea of Holly's musical maturity.

TABLE 1. The set list of Holly's last gig in The Buddy Holly Story. In grey shading are the songs performed in medley in the film.

\begin{tabular}{|l|}
\hline "True Love Ways" \\
\hline "That'll Be the Day" \\
\hline "Oh Boy!" \\
\hline "Peggy Sue" \\
\hline "Maybe Baby" \\
\hline "Not Fade Away" \\
\hline $\begin{array}{l}\text { End credits: "True Love Ways" } \\
\text { (instrumental, arranged by Joe } \\
\text { Renzetti) }\end{array}$ \\
\hline
\end{tabular}

The film thus consolidates a mythopoetic trend, which, twenty years after the events narrated, already saw Holly's place among the Olympians of the rock canon well established. A leading role in this process of consecration was played both by bands such as the Beatles and the Rolling Stones, who during the 1960s repeatedly referred to Holly as their predecessor and inspirer, and by other retrospective gazes which, in the 1970s especially, catalysed the nostalgia for the "Golden Age" of American popular culture. Along with Grease (1971; dir. Kleiser, 1978) and American Graffiti (dir. Lucas, 1973), it was famously Don McLean who poetically conflated "the day the music died" with the withering of teenage dreams and the start of an age of disillusion in his song "American Pie" (United Artists, 1971). ${ }^{8}$ 
Of the songs included in the film's final set list, "That'll Be the Day" is undoubtedly the one which, by the time of the film's release, already bore the highest intertextual legacy, having been quoted as the key line in the refrain of Don McLean's song, as the title of a generational British movie starring David Essex and Ringo Starr (dir. Whatham, 1973) and more recently refreshed in mass popularity by Linda Ronstadt's Grammy-winning cover version of the same (Asylum/Rhino, 1976). The process of re-semantization with regard to "Not Fade Away", on the other hand, is more deliberate, if one thinks that during Holly's career the song was issued only as the B-side of the single "Oh Boy" (Brunswick, 1957) and did not enjoy a fame comparable to his other hits (though it was performed as an encore during the Winter Dance Party Tour). However, the Rolling Stones' cover (Decca, 1964) relaunched the song and appears to be more influential in Renzetti's arrangement than the Crickets' original: as in Jagger-and-co.'s version, the beat is considerably faster, and the instrumentation includes a heavier guitar part and a blues harmonica (see also Laing 2010: 149). ${ }^{9}$ Overall, Rash's movie certainly underlines the prophetic connotation overlaid on Holly's songs after his premature death; nevertheless, by soberly downplaying the ominous teleology implicit in the fatal crash, it also emphasizes the suddenness of the event and points to the selfevidence of Holly's musical legacy. The substantial time stretch occupied by the final performance scene (lasting in total about eleven minutes) creates a sense of time suspension, abruptly interrupted by the final stop-motion shot. Interestingly, this time suspension is accomplished by bending the time flow of the filmic narration into the real time of the performance experience. As reviewer Judith Bloch (1978: 45) aptly inferred,

The last shot of the film (...) clearly conveys this sense of a life unfinished, and a question unanswered. But this questioning, tentative tone has been captured in a more subtle way throughout the film: the split-second spontaneity emphasizes the delicacy of time itself, and makes a skillfully quiet statement of awe in the face of timely genius, and untimely death.

The film received generally good reviews, thanks largely to Busey's convincing portrayal. Bloch (1978: 44) commented that the "excellent quality of the photographic direction combines with the consistently fine acting of Busey to evoke a behind-the-scenes truth, a reality not of historical fact but of the intimate details of personality, and of the finely tuned nuances of physical movement" (emphasis added). The kind of "sensory authenticity" that stems from the actor's performance is primarily linked to the director's decision to shoot the performance scenes live, and, due to budget restrictions, to edit them from only one or two takes each. ${ }^{10}$ The imprecisions in Busey's performance, which would not be acceptable in an official recording, conversely bring to the film the "unpolished beauty" noticed by Bloch (ibid: 45). The effect of liveness emerges precisely by allowing minor flaws and raw 
features that, whilst not compromising the overall outcome of the performance, demystify it (see Feuer 1983: 42-44) by making it "more real", to quote Rash (Rash and Busey, 1999). The choice to digest Holly's hits through a medley may also be interpreted as a device designed to convey a sense of real-time duration. Starting with the fourth song of the medley, "Maybe Baby", Busey begins to show some fatigue in his voice and his timing. Contemporaneously, two other spontaneous unscripted events occur to enhance the documentary-like feature of the sequence: first Busey clumsily struggles to disentangle the guitar cable from his leg (Fig. 2a) and then waves, presumably at the stage mixer, to increase the volume on his monitor (Fig. 2b). By the time the medley reaches the last song, Busey's guitar playing is also affected by a few involuntary imprecisions.
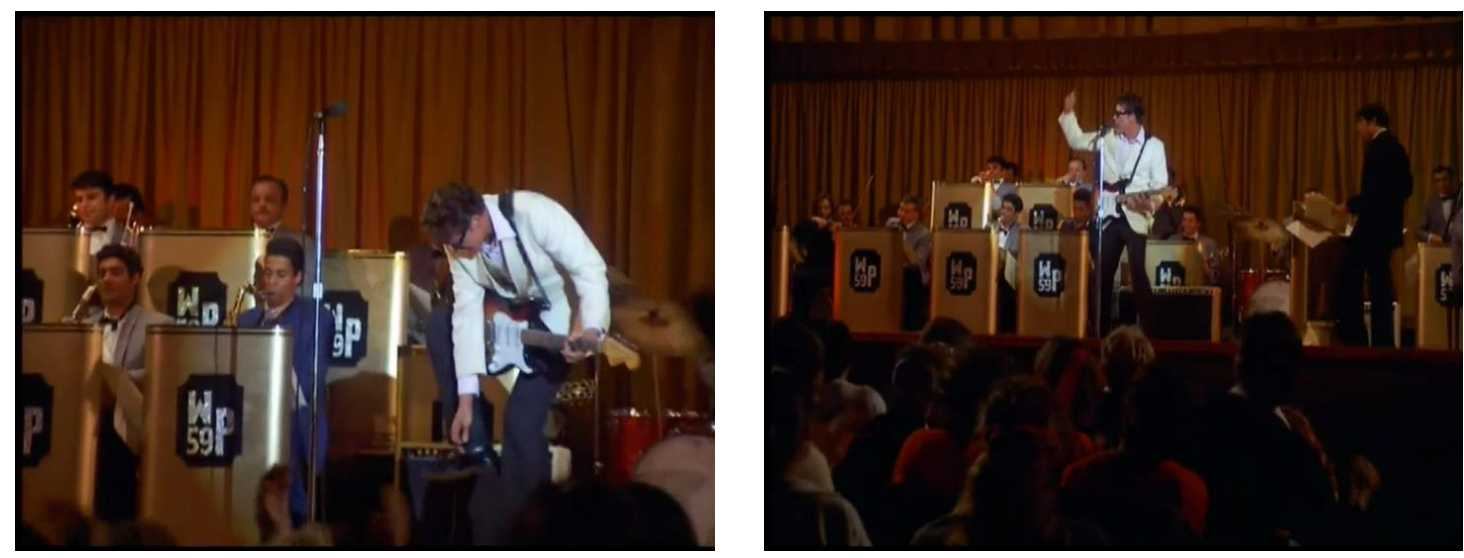

a

$\mathrm{b}$

FIGURE 2. The Buddy Holly Story (dir. Rash, 1978), film stills (a: 1:47:47; b: 1:48:07). Innovisions - ECA Productions - Columbia Pictures.

In commenting on the seminal live performance acts in The Jazz Singer (dir. Crosland, 1927), Thomas F. Cohen (2012: 13) outlined that "it would appear that the immediate demands of performing music occupy the singer too thoroughly to allow him to act". The same can be said for the sequence analyzed above. The prevalence of music performing values over acting values unearths a specificity of the incorporation of musical performance into cinema and the processes triggered to validate its aura. The balance between narrative and spectacle is in theory always called into question whenever a singer/musician is filmed and a musical act with its own peculiar dramaturgy is brought into play. The performative polarization established by such a presence on the screen inevitably calls for a renegotiation of the film's relation to the audience, whose role may shift temporarily from cinematic to musical spectatorship. "Performances", wrote David Neumeyer (2000: 45), "delay, and sometimes disrupt, the flow of narrative, as they require that we pay attention to them in order to recognize and appreciate them as artistic events - that is, as musical performances in the usual sense". This leads me to maintain that one 
kind of authentication that The Buddy Holly Story and the next examples seek to convey by filming musical performance live is the sense of embodied affectivity that a live performance is reputed to have. This shares communalities with Allan Moore's (2002: 220) definition of "'second person' authentication, or authenticity of experience, which occurs when a performance succeeds in conveying the impression to a listener that that listener's experience of life is being validated, that the music is 'telling it like it is' for them" (emphasis in the original).

\section{Building "neoclassicism": Walk the Line (2005)}

James Mangold's film about Johnny Cash is considered, together with Ray (dir. Hackford, 2004), a prototype of the renaissance of the biopic genre in the 2000s (see G. D. Smith 2009; Brost 2010; Schlotterbeck 2010; Spirou 2012). It was the top-grossing biopic between 1978 and 2012, ${ }^{11}$ accounting on its own for around one sixth of the entire revenue of biopics in the United States in those years (Spirou 2012: 1). In order to achieve such great popularity, it was necessary for the film to absorb features of the Hollywood blockbuster so as to appeal to a much wider public than that represented by the fans of Johnny Cash and country music. Walk the Line takes a segment of Cash's long career, from his début to the end of the 1960s, and describes the salvific effect that the love story with June Carter had on Cash's search for existential and aesthetic maturity.

Performance has an unquestionable centrality in the film narrative. Rendering Cash's characteristic sound was one of the director's chief concerns (see Mangold, 2005). In choosing T-Bone Burnett as executive music producer and arranger, Mangold placed his film in continuity with the recognisable standard of integrated compilation soundtracks that Burnett had consolidated in movies such as the Coen brothers' The Big Lebowski (1998), O Brother, Where Art Thou? (2000) and The Ladykillers (2004), as well as in Wim Wenders's Don't Come Knocking(2005), and which would continue after Walk the Line in musical films such as Across the Universe (dir. Taymor, 2007), Crazy Heart (dir. Cooper, 2009), Bloodworth (dir. S. D. Taylor, 2010) and Inside Llewyn Davis (dir. J. and E. Coen, 2013). For Walk the Line, Burnett also worked as music coach with the actors, who sing and play all the songs live. In his commentary to the film, Mangold insisted on the idea that the actors were supposed to convey a sense of accomplishment-through-practice in their performing, a sense of self-achievement that was expected to render what Johnny Cash's craftsmanship was understood to be about:

[W] hat [T-Bone Burnett] shared with me was this idea that in order to make the actors feel like musicians you have to give them a chance to grow as musicians. We gave them three months in a studio where we let them come in every day and practice and play, record themselves, hear a playback, probably get 
disgusted and disappointed with where they're at and how they sound, but come back the next day and work it harder (Mangold, 2005).

Mangold sought a similar path to authentication in portraying the concert audiences. Performances in the film needed to retain the kind of "southern energy" that accompanied Cash's concert career. This is why local crowds mainly from the Memphis and Nashville areas were hired as extras for the performance scene audiences. In the intent of the director, the excitement of such an audience on the set witnessing a movie star impersonating a legend of country music that "they respected and loved" was "critical for [the] scene[s] working" (Mangold, 2005).

The film specifically selects one live performance as the pivot for the story, namely Cash's concert at Folsom Prison in 1968. The public memory of that performance is encapsulated in one of Cash's most successful albums, At Folsom Prison (Columbia, 1968), which marked his return to the scene after a period of isolation due to drug abuse. As schematized in Figure 3, three quarters of the film's narrative is framed as an extended flashback revolving around the backstage of that very concert.

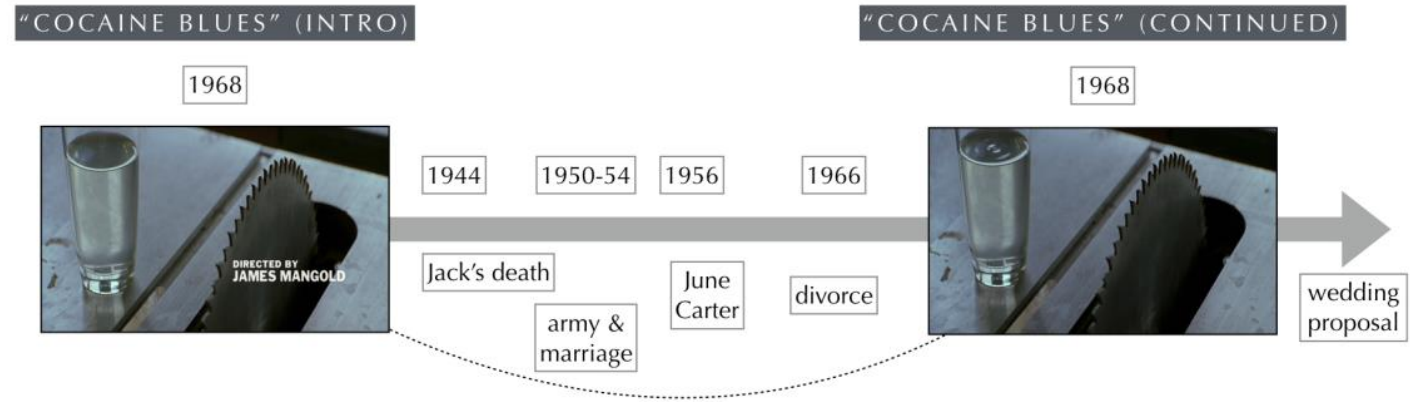

FLASHBACK

FIGURE 3. Schematic rendition of Walk the Line's storyline (dir. Mangold, 2005). Film stills (0:02:26; 2:05:27) Mars Media Beteiligung GmbH \& Co. Filmproduktions KG and Twentieth Century Fox Film Corporation.

A phenomenological description of the opening sequence can help us unpack the core of the film's content and especially the value that performance plays in it. An inward movement of the camera eye brings the spectator through the thick walls of what we soon understand to be Folsom Prison. The movement is underpinned by a low-frequency muffled roar, which, indefinite at first, gradually discloses itself as a country bassline vamp with its typical I-V bass alternation. A first, highly reverberated guitar phrase emerges in sync with the shot of the refectory door and, coincidentally, the other two instruments that make up the vamp, the guitar and the 
drums, become more and more distinct. Meanwhile, a second sound element emerges from the drone, namely a beating of feet on the floor and a clapping in time with the vamp, which is shortly afterwards de-acousmatized by being associated with the audience of prisoners gathered in the refectory. Only at this point does it become clear that a live performance is taking place, with a band lingering on the one-chord vamp while waiting for the frontman to make his entrance. The musicians' embarrassed gazes at the door also expose the one facet of country music that its detractors tend to criticize: its instrumental shallowness and harmonic monotonousness (the best they can do to vary the unpleasant waiting is to switch to the dominant and return to the tonic). In other words, even the least musically educated filmgoer would understand that this is not "intro music", but an unplanned filling-in as the musicians play for time. Just before the waiting has become too long, the movie cuts backstage, where we make our first acquaintance with Joaquin Phoenix's portrayal of Johnny Cash. The warden off-screen is calling Cash by name, trying to distract him from the circular saw that has caught his attention. The country vamp has again become muffled, as it was previously. Another cut brings us suddenly to a different place and time accompanied by the unmistakable introductory guitar launch of Blind Willie Johnson's recording of "Dark Was the Night, Cold Was the Ground" (Columbia, 1927-28).

In what sense are these audiovisual features the expression of a meaningful dramaturgy? The two main musical presences of the sequence - the vamp and Blind Willie Johnson's guitar intro - can be respectively intended as genre synecdoches (Tagg 2012: 524-28) of country music and Delta blues. The trajectory from the former to the latter is dramaturgically signified by the way each audiovisual element is presented (Fig. 4, third column). The muffled sound bears a pathematic value, its low frequencies communicating physically and pre-rationally with the spectator's body before they are perceived as country music. They carry added connotations of urge and tension, while the repetitiveness builds up an expectation for new developments. However, when the film cuts backstage, the muffled sound does not convey exactly the same connotations it had earlier: it has now been subjectivized by the fact that we identify it with Cash's point of hearing. The fact that Cash is caught up in his thoughts and that he is sweating makes the sound gain a more intimate perspective, conveying a sense of fatigue and perhaps mental or physical instability. The latter is emphasized by the circular saw, which is fraught with a sense of peril and can be metaphorically related to the title of the film (and Cash's hit), Walk the Line, suggesting the presence of a traumatic watershed in the biography of Johnny Cash.

Soon afterwards we will learn that the musician's childhood was traumatically marked by his brother's death in an accident with a circular saw. But the sense of danger and risk generated by the tool can be read in many ways at this early point in the film, one of which is tentatively musical: following the trajectory from country to blues that is created by the opening sequence, we are in fact following the 
symbolic connection, which - according to a certain narrative of Cash's musical style - had the musician "walk the line" between white country music and the "authentic" black roots of blues. In short, this classic trajectory towards authenticity, which has been exploited to portray the careers of countless American musicians in popular media, is validated by a sensory dramaturgy of bodily, intimate audiovisual perceptions.

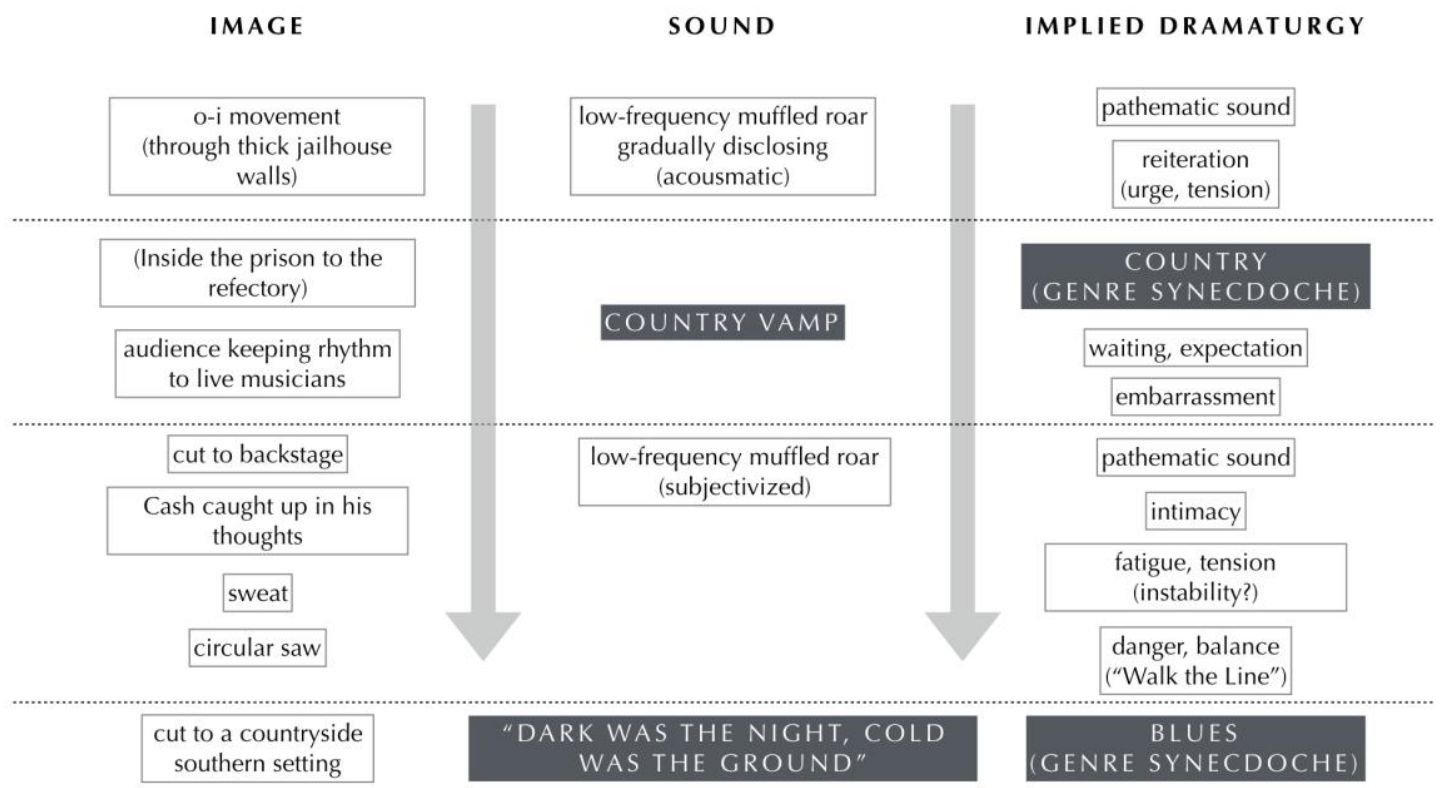

FIGURE 4. Schematic rendition of Walk the Line's opening sequence.

The reprise of the Folsom performance after the long flashback that takes up two thirds of the film is opened by the same shot of the circular saw. Crucially, the musical trajectory described above is here re-affirmed in a symmetrical way: the concert sequence is prepared by the entrance of Blind Willie Johnson's guitar standard, underscoring Cash's achievement of self-awareness while reading the letters received from his many convicted fans. As schematized in Figure 5, the allegory of the "descent into hell" (here represented by drug addiction) to experience his true self (the blues) is dubbed in the film by the choice of "Cocaine Blues" as the one track epitomizing the Folsom show. It is less relevant to the film's economy that chronological and historical factuality are reshaped by this allegorical representation: it must have seemed too prosaic an option to show that Cash had in fact entertained the idea of performing in jailhouses for at least eight years (long before hitting rock bottom in his drug addiction) or that he eventually accomplished this by gaining favour with Bob Johnston, the A\&R at Columbia Records (Streissguth 2004: 59-64) — rather than challenging his record company alone, as narrated in the film. 
There is not one single moment in the official album At Folsom Prison that unequivocally matches what is portrayed in the film. Of the total 3 minutes and 50 seconds taken by the reprise of the "Cocaine Blues" sequence, 57 seconds are focused on the backstage dialogue between Cash and the penitentiary warden, and one minute and 38 seconds on the introductory jokes made by Joaquin Phoenix on stage, leaving only 1 minute and 14 seconds for the actual song. (This is a notably lower proportion compared to the time accorded to musical performance in the final sequence of The Buddy Holly Story).
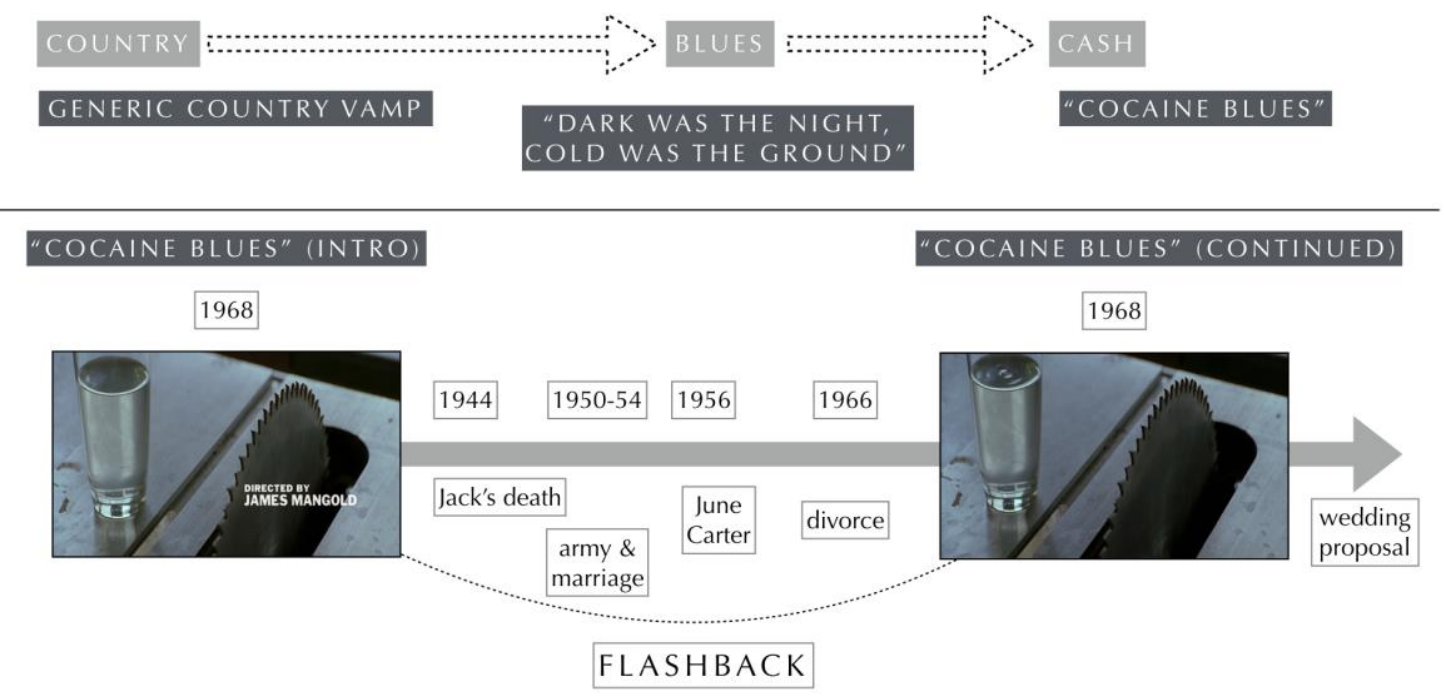

FIGURE 5. Schematic rendition of Walk the Line's (dir. Mangold, 2005) overarching music dramaturgy, with respect to the performance treatment. Film stills (0:02:26; 2:05:27), Mars Media Beteiligung GmbH \& Co. Filmproduktions KG and Twentieth Century Fox Film Corporation.

"Cocaine Blues" is featured in the official Folsom recording, but there is no trace there (nor at any other moment in the album) of the long introductory vamp that plays such a crucial role in the film. None of the several jokes collected in-between songs in the album are accompanied by music as they are in the film. The way the concert unwinds as is documented on record is much less kinetically driven than the single performance number in Walk the Line. As for the way Joaquin Phoenix delivers his interpretation of "Cocaine Blues", one must note that his performing style-which works very effectively in the film—is quite unlike Cash's. Phoenix, so to say, rocks the original country style of the song, standing in front of the mike as a rock frontman and projecting his singing with energy almost aggressively; his bodily presence and facial expressions emphasize the first-person narrative of the lyrics, as if he were under the effect of cocaine at that very moment. Cash's voice in the live album track, on the other hand, is clearly weary, ostensibly adding to the raw fascination of the recording. Another sonic divide between the album track and 
the film track can be drawn in that the frequency band-width of the former is considerably (and unsurprisingly) thinner than in the film track. ${ }^{12}$ The latter displays a prominence of low frequencies that make it more akin to a current pop-rock track than to a 1960s country track. This of course reflects the fact that listening standards have changed over time and that the film has adjusted country music's affordance to the new production values of cinematic sound immersion.

As for the visual rendition of the performance, various sources can be taken into account. The angle chosen to frame Phoenix's face in the backstage shots seems to be vaguely reminiscent of the cover picture of the Folsom LP (Fig. 6).

The concert was not filmed, so the visuals of the performance may be influenced, on the one hand, by the several photographs taken by Jim Marshall during the event (now republished in Streissguth, 2004), and on the other, the footage from Cash's equally famed concert at San Quentin a year later, which, besides being released as a live album (At San Quentin, Columbia, 1969), was broadcast by Granada Television (Johnny Cash in San Quentin, dir. Darlow, 1969) (Fig. 7).
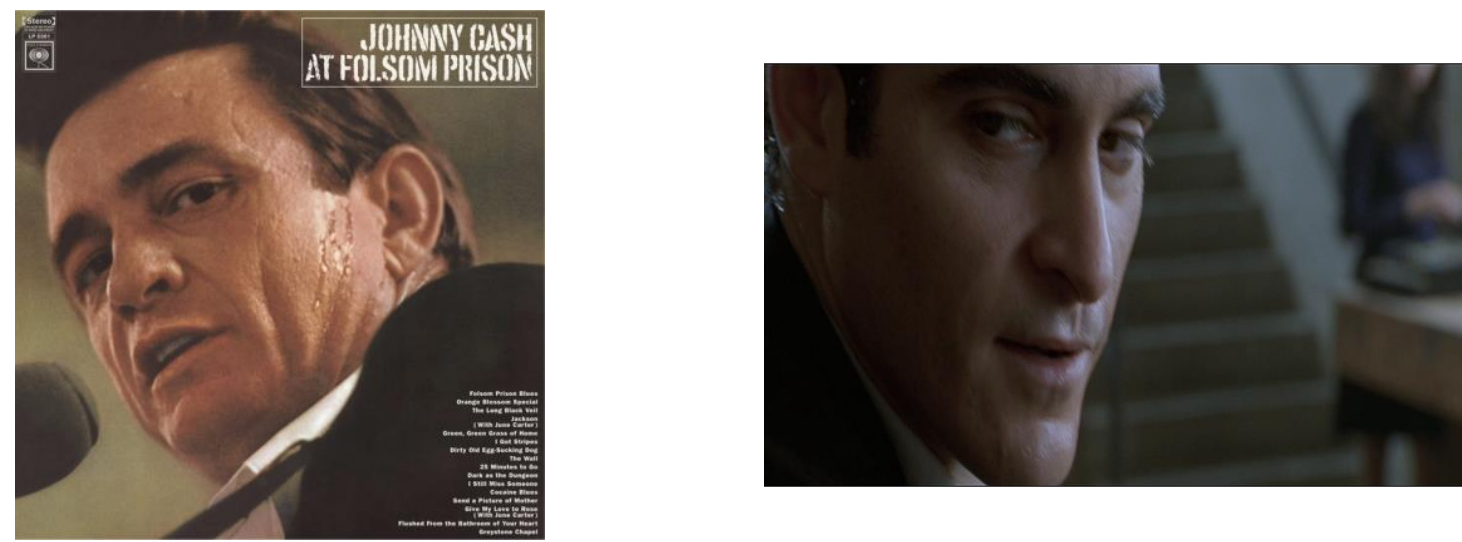

FIGURE 6. Visual comparison of the shooting angle in the cover of At Folsom Prison (left)

(1968, Columbia Records) and in Walk the Line (right) (dir. Mangold, 2005), still: 2:05:55. Mars Media Beteiligung GmbH \& Co. Filmproduktions KG and Twentieth Century Fox Film Corporation (right).

Some of the jokes immortalized by Cash during the Folsom and San Quentin concerts are condensed into the film scene. The conflation of these two concerts is an example of how biopics renegotiate public memory, by selecting and combining contiguous events and therefore creating deliberate perspective effects that bypass the repetitiveness and prosaicness of music making: exceptions notwithstanding, Hollywood biopics tend to refrain from exposing musical performance as routine, which would lead them to disclose that an event that is thought to be extraordinary became in fact a well-selling formula to be repeated over time. ${ }^{14}$ 

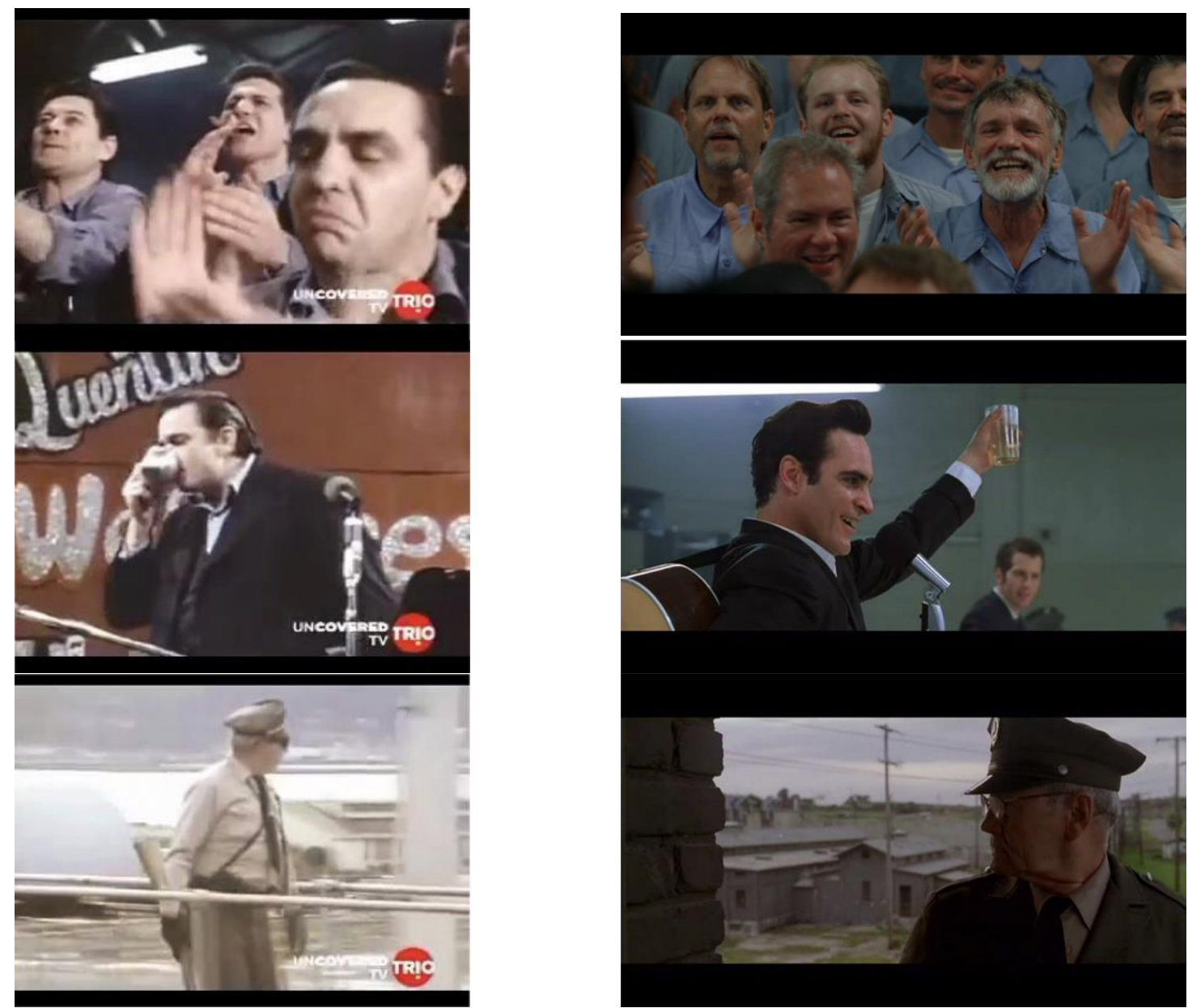

FIGURE 7. Visual comparison of the performance treatment in Johnny Cash in San Quentin $^{13}$ (dir. Darlow, 1969, ITV) (left) and Walk the Line (dir. Mangold, 2005). Mars Media Beteiligung $\mathrm{GmbH} \&$ Co. Filmproduktions KG and Twentieth Century Fox Film Corporation (right).

\section{Sound design and the ideology of cinematic performance: Get On Up (2014)}

In 2014, Jagged Films, the production company owned by Mick Jagger, released both a feature-length biopic and a documentary for the network HBO about James Brown, entitled, respectively, Get On Up (dir. T. Taylor, 2014) and Mr. Dynamite: The Rise of James Brown (dir. Gibney, 2014). Both films place Brown's concert at Boston Garden at their narrative climax, and more precisely at their golden ratio point. The event, which "has become a major chapter in the telling of Brown's life" (R. J. Smith 2012: 192), also represents one of those moments of intersection between US political history and popular music that has rendered it the subject of frequent reference in popular culture. ${ }^{15}$ The concert was telecast live by WGBH-TV (Live at Boston Garden: April 5, 1968, dir. Atwood, 1968) in the hope that people from Boston's black neighbourhoods would refrain from rioting in the streets 
following the assassination of Martin Luther King — a stratagem that actually proved successful.

By the time the biopic was released, the footage of that broadcast had already been reissued on DVD by Shout! Factory in 2008, in a box set that also included the documentary The Night James Brown Saved Boston (dir. Leaf, 2008) and the footage of another James Brown concert at the Apollo theatre in the same year. ${ }^{16}$ Ironically, the most memorable moments of the Boston Garden performance were not actually musical: (1) Brown's spoken tribute to King; (2) his diplomatic introduction of Kevin White, the Mayor of Boston, to the audience, with words that "were perfect in that moment, Brown establishing authority for himself and for the mayor at the same time" (R. J. Smith 2012: 192); and, most notably, (3) the delicate moment in which Brown interrupted the concert and managed to convince the people who were invading the stage and being violently pushed back by the police to step back and let him finish the show.

One interesting detail about the way this last episode is documented in the original footage is that the broadcast director, by switching to a camera placed at the rear of the stage (Fig. 8), chooses an awkward shooting angle to display the heated situation at the front of the stage, where Brown is trying to calm down the crowd and rein in the reaction of the police.

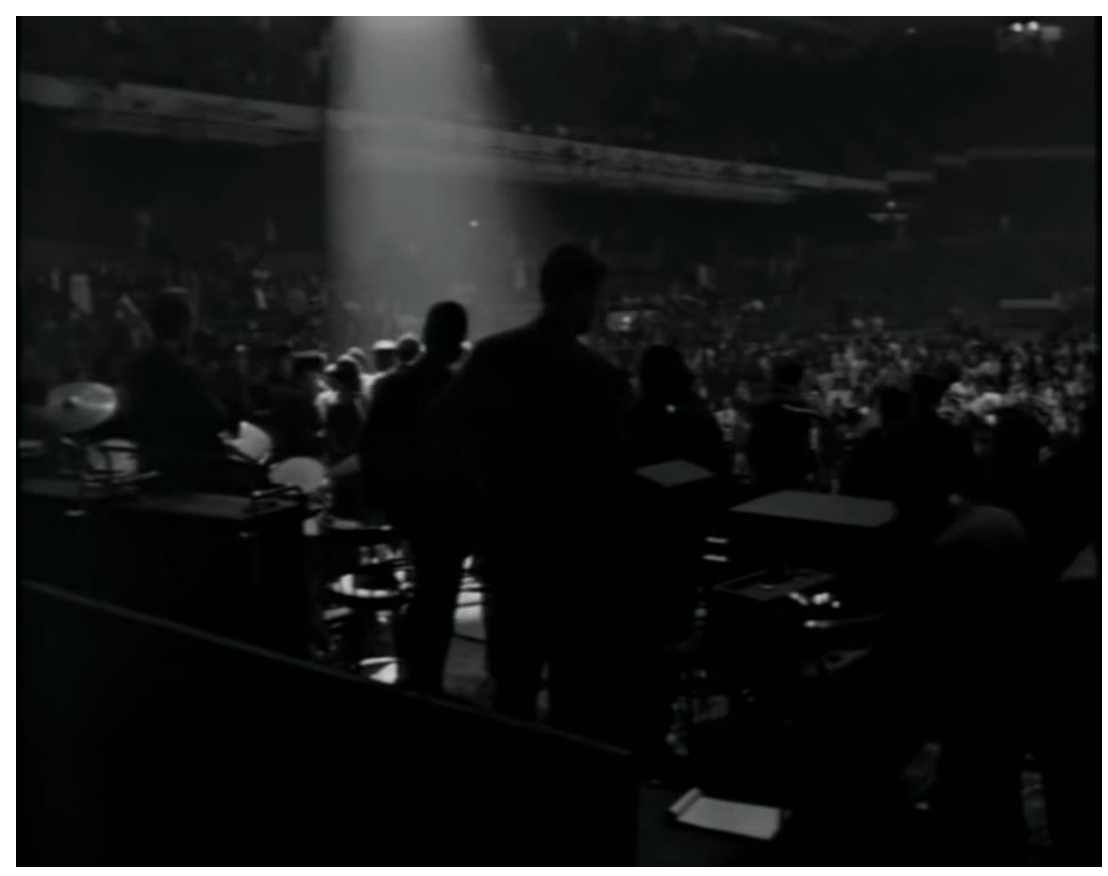

FIGURE 8. James Brown: Live at Boston Garden: April 5, 1968 (dir. Atwood, 1968), film still (1:17:08). 1968 WGBH, 2008 Shout!Factory.

The viewer's perspective is thus kept at a distance from the core of the event, with the deliberate intent of not showing too closely what had all the prerequisites to light the fuse of an explosive reaction around the city, i.e. "white cops 
aggressively confronting black youths on live TV" (R. J. Smith 2012: 192). The result is that for a part of the episode we can only hear Brown's voice and grasp some of the other voices surrounding him. In the moment of highest tension, when Brown realises that his authority is under threat, he raises his voice: if anything still speaks to us powerfully of that particular moment, it is its openness. Brown takes a huge risk in keeping the officers away and engaging directly with the audience, and whilst he eventually succeeds, uncertainty is palpable for some instants. The extemporary decision of the live broadcaster to visually "censor" the events stands out as a performative reaction to the unpredictable direction taken by the show: it is therefore a trace of "the possibility of the unexpected" which lan Inglis (2006: xv) finds such an important feature of rock performances.

Turning to the biopic, the first thing to note is the fact that the television broadcast does not play any significant role in the dramaturgy of this scene. In the preceding sequence the broadcast is mentioned but its function is misreported: in the film it is Dan Aykroyd, in the role of manager Ben Bart, who tries to convince Brown (Chadwick Boseman) that cancelling the concert in order to avoid likely disorders being "broadcast to the rest of the world" would be a good idea; after this single mention, the television's role is irrelevant throughout the concert scene, except for the fact that TV cameras are visible from time to time. In the strategy it deploys to dramatize the event, the film seems interested primarily in extolling Brown's role as the saviour of the situation, thus reminding us of George F. Custen's (1993) critical assessment of Hollywood's construction of public history.

Get On Up

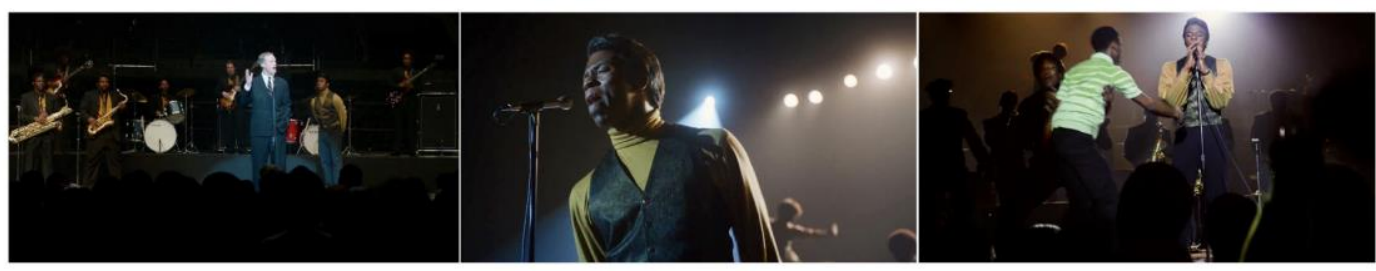

"I Can't Stand Myself

Mayor's speech

"I Got the Feelin" (When You Touch Me)" [interrupted]

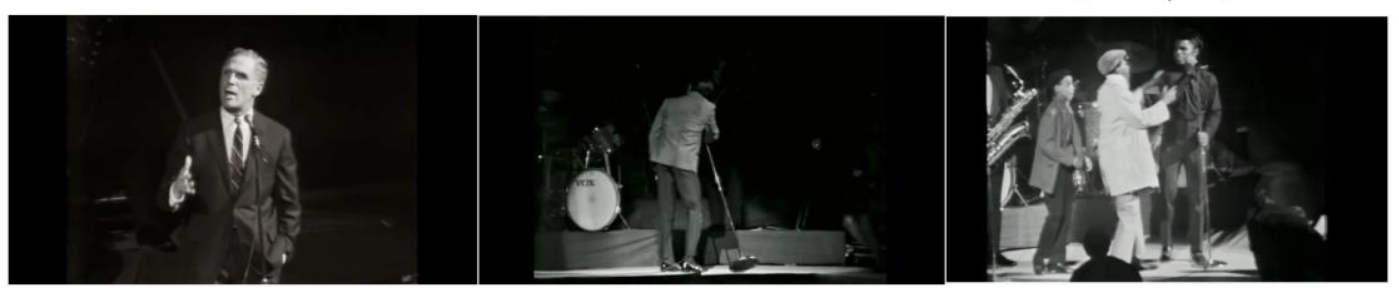

James Brown live at Boston Garden: 5 April, 1968

FIGURE 9. Visual comparison of the performance treatment in the biopic (up: 1:28:21; $1: 29: 14 ; 1: 30: 36$ ) and in the original footage (bottom: 0:07:00; 0:49:25; 1:15:23). 2014 Universal Studios (top); 1968 WGBH, 2008 Shout!Factory (bottom). 
The performance is condensed thus: (1) part of Mayor White's introductory speech is reported; (2) Brown's track "I Got the Feelin'" (King, 1968) is presented in medley with (3) "I Can't Stand Myself (When You Touch Me)" (King, 1967), the song that is interrupted by the crowd; then (4) it is Brown's turn to address the crowd in an attempt to re-establish order, after which (5) the music starts again (Fig. 9). The sequence lasts approximately two minutes in total. According to the end credits, the audio to which Boseman and the band play back is not taken from the soundtrack, admittedly poor, of the footage, but from the live album Say It Live and Loud: Live in Dallas 08.26.68 (PolyGram, 1998).

The sequence of events is accurate enough per se, and yet the way in which the audiovisual details are organized provides us with further non-neutral information. The choice of "I Got the Feelin"" is appropriate given that the track was one of Brown's major hits in 1968, but appears to be motivated by the way the show has lately been mediatized, especially following the original footage re-release in 2008. It is worth noting here that the characteristic close-up of Boseman singing the hook "Baby baby baby..." is patterned after the opening shot of the above-mentioned documentary The Night James Brown Saved Boston, the same shot that also opens the trailer of the triple DVD set issued by Shout! Factory (Fig. 10). Even more surprising is the fact that this shot never actually occurs as such in the televised footage-it arguably consists in the digital blow-up of the original framesuggesting that Tate Taylor was influenced more by the contemporary remediations of the event than by careful analysis of the "original" document.
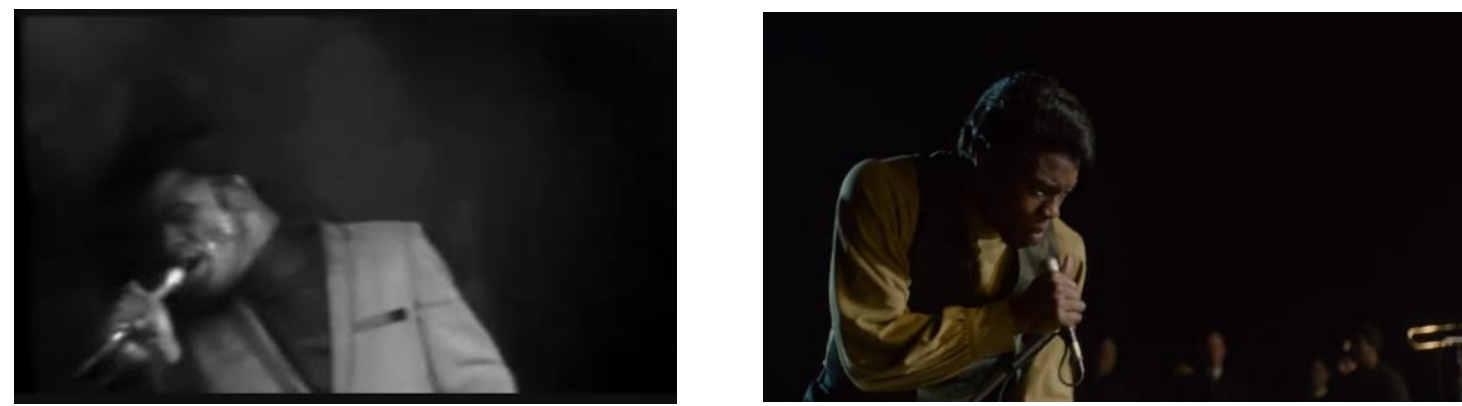

FIGURE 10. Visual comparison of Brown singing the hook "Baby baby baby..." in "I Got the Feelin'" in The Night James Brown Saved Boston (dir. Leaf, 2008) (left still, 0:00:25) and Get On Up (dir. T. Taylor, 2014) (right still: 1:29:36). 2008 Estate of James Brown (left); 2014 Universal Studios (right).

As much as the complexity and, to a certain extent, also the laconicism of the original footage give way to the unpredictability of the event, I would argue that the biopic, on the contrary, channels the whole performance into a simplistic binary opposition between Brown (the hero) on one side and the authorities (the villains) on the other, leaving the audience (the mass) in the background. In this way, it constructs a story that suits the schemes of a Hollywood mainstream narrative film. 
Hints of this interpretation are not merely visual, but are more subtly conveyed by means of a meticulous sound dramaturgy that is bound to exert its function prerationally and affectively. On the dramaturgic side, Jason Davis enacts an antagonistic portrayal of Mayor White, acting as if the man was in principle hostile to Brown and his whole enterprise. When the show is interrupted by the invading crowd, the mayor is framed sniggering "Oh no!" in a sarcastic tone, implying that he would not mind seeing a bunch of black people beaten up by police. ${ }^{17}$

Another visual element that plays a driving dramatic role is the presence of tracker pit bull terriers on the police officers' chains, a detail that is not visible in the original footage. Were the dogs not attributed a dull disturbing function in the sound dramaturgy of this sequence, their role would be otherwise almost irrelevant. Clearly, however, the choice to include them in the shooting responds to the need to heighten the threatening presence of the police on stage, and this is chiefly achieved by characterising the sound of the dogs barking in a hyper-realistic way. During the mayor's introduction we hear the barks and the dog chains creaking, conferring a sinister hypocritical undertone to his conciliatory speech. The barking returns afterwards, this time in an eerily reverberated shape, as Brown pronounces the crucial sentence "We are black! We are black! Let's represent ourselves now". Here the threat of police repression on the black community (still a very hot topic in U.S. public discourse in 2014 and today) becomes dauntingly clear.

The most decisive manipulatory sound design technique, however, is reserved for Brown's speech. By silencing the sound of the audience's protests in sync with Brown raising his voice, the film establishes the performer's authority over the crowd and builds up a sense of expectation for what he will say next. The technique of creating a sudden unreal silence - in this case enhanced by a change of sonic perspective in Boseman's voice, which becomes suddenly more reverberated - is a typical rhetorical Hollywood device used to underline memorable moments in the public speech trope, and would be likely followed by the gradual entrance of an orchestral cue sustaining the oratorical crescendo of a speech. Here the score is not present, but its function is taken up by the applause following Brown's address "Are we together or we ain't?" and the reprise of the song. To sum up, what in the original footage appeared as an open moment charged with risk and uncertainty, in the biopic is reoriented towards the peak-moment in which the star will "write" history.

Extending Auslander's take on "the performativity of performance documentation" (2006) to fiction cinema, this example could be read in the terms of a theatrical rendering of a mediatized historical event. Auslander's polarization between the "theatrical" and "documentary" attitudes embedded in performance documentation serves to argue against an ontological divide between non-fiction and fiction, and in favour of a shift of attention to the experiential relation that exists between the viewer and the media artefact. To this end, Auslander (2009) has elaborated two theoretical notions, drawing on Benjamin and Gadamer 
respectively. The first is the concept of the "reactivation" of the past into the present: "Each time the reproduction is beheld, the original is reactivated as a production in the present tense" (ibid.). In this respect "the original context in which a performance took place is part of what makes it significant to the audience for its mediatizations". The second is the concept of the "fusion of horizons", which "occurs in the encounter between a historical text and its present-day beholder". "The current horizon", continues Auslander, "is a product of the past, of history, and our assumptions about past horizons are always projected from the present horizon". Put differently, the viewer and her subjective perceptions are decisive in the way the experience of the past is introjected. At the same time, as my emphasis on the orienting function of sound design seeks to illustrate, the viewer's experience is to a certain extent channeled and predetermined by media apparatuses. As film semiotician Ruggero Eugeni put it, "media experience is a kind of projected experience, and media can be defined as devices which implement an experiential design" (2011: 11). Thus, an analysis of the kind I have presented here, comparing different film renderings of the same event, can encourage viewers to critically engage with the ways in which the mass-media industry tends to instil predesigned experiences of (music) history.

\section{Conclusions}

I hope to have shown through my examples that biopics aim to reorganize the public memory of a past musical event and to emotionally reach audiences as mediatized performances. While their performative outcome may be contingent on the historical context of the film's production, it also depends on the changing conditions of their reception. In all cases, media texts demand to be unpacked, deconstructed for their sensory and affective potential to be singled out and understood. ${ }^{18}$ I have also observed that biopic's remediation gains performative impact often at the price of historical accuracy. Whether this is a logical implication or a singular side-effect, remains to be debated. The cases I presented show a nonexhaustive yet common typology of sensory remediation of canonized musical performances, which tends to strip history of its ambiguities to inform present musical experience with dense self-standing stimuli. In so doing, facts are manipulated and interpretations oriented, political and ideological agencies are frequently embedded or even disguised in the texts. And yet, if we understand what occurs in a movie theatre as a kind of mediatized performance, the bond that is created between the film and the audience can be read as a counterbalance of the narrative licensing over historical facts. In the potentially unlimited and centrifugal access to music we have today, the contemporary biopic may serve the purpose of organizing, selecting, and configuring a sense of music history lasting the space of a film, while securing new markets for old music in a phase of unprecedented 
uncertainty in the music industry. To subtract a historical performance from the indistinct audiovisual "cloud" and re-connect it with a (rather than the) history of production, reception, and signification might be one widely overlooked cultural agency that musical biopics are enacting under our sight.

\section{Endnotes}

1 "Trace and aura. The trace is appearance of a nearness, however far removed the thing that left it behind may be. The aura is appearance of a distance, however close the thing that calls it forth. In the trace, we gain possession of the thing; in the aura, it takes possession of us" (Benjamin, 2002: 447).

${ }^{2}$ For the theoretical notion of remediation, see Bolter and Grusin (1999).

3 This does not exclude the possibility that documentaries themselves reinvent and remediate the events they refer to. For a theoretical stance on this, see among others Renov (1993). For the relationship of pop/rock biopics with history, see Inglis (2007).

${ }^{4}$ According to director Steve Rash, a scene of the plane crash was shot but then omitted from the film. On the contrary, the Ritchie Valens biopic La bamba (dir. Valdez, 1987) ends with the dramatic moment in which the news of the fatal accident reaches Valens's loved ones, followed by the funerals.

${ }^{5}$ That particular phone call is one of the most frequently quoted anecdotes concerning the unfortunate event that followed; not by chance does the film carefully reproduce the telephone, still preserved today at the Surf Ballroom Museum, which was even then one of the most iconic memorabilia of Holly and Valens's last day.

${ }^{6}$ Bunch was stuck at the hospital with frostbite during the Surf Ballroom gig and was thus replaced by the Belmonts' bass singer Carlo Mastrangelo (Lehmer 1997: 91).

${ }^{7}$ The tenor saxophone session player was reported to be Abraham "Boomie" Richman, formerly from the Benny Goodman band (Anka and Dalton 2013: Chapter 2).

${ }^{8}$ According to Rash, "American Pie" constituted his main inspiration to make the movie (Rash and Busey, 1999).

${ }^{9}$ By the year of the film's release, a cover version of "Not Fade Away" had also been included in Tanya Tucker's successful album TNT (MCA, 1978). Furthermore, Not Fade Away was the title of an earlier biopic produced by Jerry Allison of the Crickets, which was being shot, with Busey starring in the role of the drummer, before it was superseded by Rash's film. Finally, Not Fade Away is the title of a 2012 film by David Chase, which, though not quoting directly Holly's song, is set in the 1960s American music scene.

${ }^{10}$ According to the director, the final performance scene was recorded completely live on a 24-track portable studio truck and was reportedly shot in two takes without rehearsals (Rash and Busey 1999).

${ }^{11}$ It is reasonable to assume that this primacy persists also between 2012 and today.

${ }^{12}$ The lowest peak of the album track is $\sim 68 \mathrm{~Hz}$ while the lowest bandwidth of the film track is comprised between $\sim 40$ and $\sim 60 \mathrm{~Hz}$. Data are extracted using the open source 
software Sonic Visualiser. Though a reliable comparison should be made by confronting the original film and the LP, my analysis is based respectively on the DVD edition of the film and the Legacy Edition of At Folsom Prison digitally issued for iTunes (2008).

${ }^{13}$ The stills are taken from a clip of "San Quentin" re-aired by Trio TV in the 1990s, which is now available on YouTube: https://youtu.be/1 zgja26eNeY?list=RDwGOfS4DoGUc. Accessed 5 February 2017.

${ }^{14}$ A similar point regarding the conflation of different performances into one is made by Brian Fauteux (2009) in his analysis of Joy Division's "Transmission" scene in Contro/ (dir. Corbijn, 2007).

${ }^{15}$ For instance, the event was at the centre of one chapter of the best-selling Pulitzer Prize non-fiction book Common Ground(Lukas, 1985).

${ }^{16}$ I Got the Feelin': James Brown in the '60s. Interestingly, the Boston Garden concert was re-published as an "Extended Edition" in 2014, possibly in an attempt to capitalize on the release of Tate Taylor's biopic.

${ }^{17}$ In Walk the Line, the prison warden is also given a similarly antagonistic role with regard to Johnny Cash and is framed in a reverse shot as Cash sarcastically dedicates "Cocaine Blues" to him.

${ }^{18}$ For a more theoretical take on this subject, see Corbella (2015).

\section{Acknowledgements}

The research supporting this article benefitted from a short-term scholarship spent at Kiel University in 2015-16 and funded by the DAAD (German Academic Exchange Service). I am grateful to the students of my courses in Kiel and at the University of Milan for their enriching discussions of the examples analysed above.

\section{References}

\section{Bibliography}

Anka, P. and Dalton, D. 2013. My Way: An Autobiography. New York: St. Martin's Press. Kindle ebook.

Auslander, P. -

2006. The Performativity of Performance Documentation. PAJ: A Journal of Performance and Art 84: 1-10.

2009. Reactivation: Performance, Mediatization and the Present Moment. In M.

Chatzichristodoulou, J. Jefferies and R. Zerihan Eds. Interfaces of

Performance. Abingdon and New York: Ashgate: Ebook Chapter 6.

Benjamin, A. 2002. The Arcades Projects. Transl. H. Eiland and K. McLaughlin.

Cambridge, Mass. and London: Harvard University Press. 
Bingham, D. 2010. Whose Lives Are They Anyway? The Biopic as Contemporary Film Genre. New Brunswick, NJ and London: Rutgers University Press.

Bloch, J. 1978. The Buddy Holly Story by Steve Rash. Film Quarterly 32 (1): 4246.

Bolter, J. D. and R. Grusin. 1999. Remediation: Understanding New Media. Cambridge, Mass. and London: The MIT Press.

Brost, M. 2010. Walking the Line: Negotiating Celebrity in the Country Music Biopic. Scope: An Online Journal of Film and Television Studies 18 (October): 1-15.

Cohen, T. F. 2012. Playing to the Camera: Musicians and Musical Performance in Documentary Cinema. London and New York: Wallflower Press.

Corbella, M. 2015. Performativity Through(out) Media: Analyzing Popular Music Performance in the Age of Intermediality. In C. Maeder and M. Reybrouck Eds. Music Analysis Experience: New Perspectives in Musical Semiotics. Leuven: Leuven University Press: 43-58.

Custen, G. F. 1993. Bio/Pics: How Hollywood Constructed Public History. New Brunswick, NJ: Rutgers University Press.

Eugeni, R. 2011. A Semiotic Theory of Media Experience. In Amsterdam School for Cultural Analysis (ACSA), International Workshop "Practicing Theory," University of Amsterdam. March 2-4 2011.

https://ruggeroeugeni.files.wordpress.com/2010/12/asca_a_theory_of_semiotic_ experience.pdf. Accessed 6 August 2017.

Fauteux, B. 2009. Television, Live Transmission: Contro/and the Televised Performance Scene. Cinephile 5 (2) (Summer, The Scene): 24-29.

Feuer, J. 1993. The Hollywood Musical. Second Edition. Bloomington and Indianapolis: Indiana University Press.

Inglis, I. -

2006. Introduction: History, Place and Time: The Possibility of the Unexpected. In I. Inglis Ed. Performance and Popular Music: History, Place and Time. Aldershot: Ashgate: xiii-xvi.

2007. Popular Music History on Screen: The Pop/Rock Biopic. Popular Music History 2 (1): 77-93.

James, D. E. 2016. Rock 'n' Film: Cinema's Dance with Popular Music. New York: Oxford University Press.

Jones, C. W. 2008. The Rock Canon: Canonical Values in the Reception of Rock Albums. Aldershot: Ashgate.

Laing, D. 2010. Buddy Holly. London: Equinox.

Lehmer, L. 1997. The Day the Music Died: The Last Tour of Buddy Holly, the "Big Bopper", and Ritchie Valens. New York: Schirmer.

Lukas, J. A. 1985. Common Ground: A Turbulent Decade in the Lives of Three American Families. New York: Vintage Books. 
Moore, A. F. 2002. Authenticity as Authentication. Popular Music 21 (2): 209223.

Neumeyer, D. 2000. Performances in Early Hollywood Sound Films: Source Music, Background Music, and the Integrated Sound Track. Contemporary Music Review 19 (1): 37-62.

Norman, P. 1996. Buddy: The Definitive Biography of Buddy Holly. London: Macmillan.

Renov, M. 1993. Introduction: The Truth about Non-Fiction. In M. Renov Ed. Theorizing Documentary. New York and London: Routledge: 1-11.

Schlotterbeck, J. 2010. "Trying to find a heartbeat": Narrative Music in the Pop Performer Biopic. Journal of Popular Film and Television 36: 82-90.

Smith, G. D. 2009. Love as Redemption: The American Dream Myth and the Celebrity Biopic. Journal of Communication Inquiry 33 (3): 222-238.

Smith, R. J. 2012. The One: The Life and Music of James Brown. New York: Gotham Books.

Spirou, P. 2012. The Musical Biopic: Representing the Lives of Music Artists in $21^{\text {st }}$ Century Cinema. PhD. Macquarie University, Sydney.

Streissguth, M. 2004. Johnny Cash at Folsom Prison: The Making of a Masterpiece. Da Capo Press: Cambridge, Mass.

Tagg, P. 2012. Music's Meanings: A Modern Musicology for Non-Musos. New York and Huddersfield: Mass Media Music Scholars' Press.

Vidal, B. 2014. Introduction: The Biopic and its Critical Contexts. In T. Brown and B. Vidal Eds. The Biopic in Contemporary Film Culture. New York and London: Routledge: 1-32.

\section{Discography}

Brown, James. 1998. Say It Live and Loud: Live in Dallas 08.26.68, Polydor, US. Cash, Johnny.1968. "Cocaine Blues", At Folsom Prison, Columbia, US.

Crickets, The. -

1957. "That'II Be the Day / I'm Looking for Someone to Love", Brunswick, US.

1957. "Oh Boy / Not Fade Away", Brunswick, US.

1958. "Maybe Baby / Tell Me How", Brunswick, US.

Doors, The. 1967. "The End", The Doors, Elektra, US.

Holly, Buddy. -

1960. "True Love Ways / That Makes it Tough", Coral, US.

1963. "Come Back Baby / Blue Suede Shoes / Ummm, Oh Yeah / You're The

One", Coral, New Zealand.

1963. Reminiscing, Coral, US.

James Brown and The Famous Flames. -

1968. "I Got the Feelin' / If I Ruled the World", King, US. 
1968. "I Can't Stand Myself (When You Touch Me", I Can't Stand Myself When You Touch Me, King, US.

Mangold, J. 2005. Walk the Line. Audio commentary on DVD. Twentieth Century Fox.

McLean, Don. 1971. "American Pie / Empty Chairs" "American Pie part 2", Vinyl, US.

Rash, S. and G. Busey. 1999. The Buddy Holly Story. Audio commentary on DVD. Sony Pictures Home Entertainment.

Rolling Stones, The. 1964. "Not Fade Away / Little By Little", Decca, UK.

Ronstadt, Linda. 1976. "That'Il Be the Day", Hasten Down the Wind, Asylum, Rhino, US.

Tucker, Tanya. 1978. "Not Fade Away", TNT, MCA, US.

\section{Videography}

Across the Universe. 2007. Dir. Julie Taymor. Revolution Studios et al.

American Graffiti. 1973. Dir. George Lucas. Universal Pictures/Lucasfilm/The

Coppola Company.

Bloodworth. 2010. Dir. Shane Dax Taylor. Dax Productions et al.

Control. 2007. Dir. Anton Corbijn. Becker Films et. al.

Crazy Heart. 2009. Dir. Scott Cooper. Fox Searchlight Pictures/Informant

Media/Butcher's Run Films.

Don't Come Knocking. 2005. Dir. Wim Wenders. Reverse Angle et al.

Get on Up. 2014. Dir. Tate Taylor. Imagine Entertainments/Jagged Films/Wyolah

Films.

Grease. 1978. Dir. Randal Kleiser. Paramount Pictures/RSO/Allan Carr

Production.

I Got the Feelin': James Brown in the '60s. 2008. 3-DVD Box set. Shout! Factory.

I'm Not There. 2007. Dir. Todd Haynes. Killer Films et al.

Inside Llewyn Davis. 2013. Dir. Joel and Ethan Cohen. CBS Films et al.

James Brown: Live at the Boston Garden, April 5, 1968. 1968. Dir. David Atwood [uncredited]. WGBH-TV.

Jimi: A/l Is by My Side. 2013. Dir. John Ridley. Darko Entertainments et al.

Johnny Cash in San Quentin. 1969. Dir. Michael Darlow. Granada Television.

La Bamba. 1987. Dir. Luis Valdez. Columbia Pictures/New Visions.

La Vie En Rose (original title La Môme). 2007. Dir. Olivier Dahan. Légende Films et al.

Mr. Dynamite: The Rise of James Brown. 2014. Dir. Alex Gibney. Jagged

Films/Inaudible Films/Jigsaw Productions.

Not Fade Away. 2012. Dir. David Chase. Chase Films et al.

O Brother, Where Art Thou? 2000. Dir. Joel and Ethan Cohen. Touchstone

Pictures et al.

Ray. 2004. Dir. Taylor Hackford. Universal Pictures et al. 
That'/l Be the Day. 1973. Dir. Claude Whatham. Goodtimes Enterprises.

The Big Lebowski. 1998. Dir. Joel and Ethan Cohen. Polygram Filmed

Entertainment/Working Title Films.

The Buddy Holly Story. 1978. Dir. Steve Rash. Innovisions/ECA.

The Doors. 1991. Dir. Oliver Stone. Bill Graham Films et al.

The Jazz Singer. 1927. Dir. Alan Crosland. Warner Bros.

The Ladykillers. 2004. Dir. Joel and Ethan Cohen. Touchstone Pictures et al.

The Night James Brown Saved Boston. 2008. Dir. David Leaf. David Leaf

Productions.

Walk the Line. 2005. Dir. James Mangold. Fox 2000 Pictures et al. 